THE LETTERS OF

T. S. ELIOT

VOLUME 6 
By T. S. Eliot

THE POEMS OF T. S. ELIOT

Volume I: Collected and Uncollected Poems Volume 2: Practical Cats and Further Verses edited by Christopher Ricks and Jim McCue

THE COMPLETE POEMS AND PLAYS

verse

COLLECTED POEMS I9O9-I 962

PRUFROCK AND OTHER OBSERVATIONS

THE WASTE LAND AND OTHER POEMS

FOUR QUARTETS

SELECTED POEMS

THE WASTE LAND:

A Facsimile and Transcript of the Original Drafts edited by Valerie Eliot

INVENTIONS OF THE MARCH HARE:

Poems I909-I9I7

edited by Christopher Ricks

THE ARIEL POEMS

THE WASTE LAND

OLD POSSUM'S BOOK OF PRACTICAL CATS

\author{
plays \\ MURDER IN THE CATHEDRAL \\ THE FAMILY REUNION \\ THE COCKTAIL PARTY \\ THE CONFIDENTIAL CLERK \\ THE ELDER STATESMAN
}

literary criticism

THE SACRED WOOD

SELECTED ESSAYS

THE USE OF POETRY AND THE USE OF CRITICISM

THE VARIETIES OF METAPHYSICAL POETRY

edited by Ronald Schuchard

TO CRITICIZE THE CRITIC

ON POETRY AND POETS

FOR LANCELOT ANDREWES

SELECTED PROSE OF T. S. ELIOT

edited by Frank Kermode

THE COMPLETE PROSE OF T. S. ELIOT: THE CRITICAL EDITION

Volume I: Apprentice Years, I905-I9I 8

edited by Jewel Spears Brooker and Ronald Schuchard

Volume 2: The Perfect Critic, I9I9-I926

edited by Anthony Cuda and Ronald Schuchard

Volume 3: Literature, Politics, Belief, I927-1929

edited by Frances Dickey, Jennifer Formichelli, Ronald Schuchard

social criticism

THE IDEA OF A CHRISTIAN SOCIETY

NOTES TOWARDS THE DEFINITION OF CULTURE

letters

THE LETTERS OF T. S. ELIOT

Volume I: I 898-I922

Volume 2: 1923-I925

edited by Valerie Eliot and Hugh Haughton

Volume 3: I926-I927

Volume 4: I928-I929

Volume 5: I930-I93 I

edited by Valerie Eliot and John Haffenden 


\section{THE LETTERS OF}

\section{T. S. Eliot}

EDITED BY

VALERIE ELIOT

AND

JOHN HAFFENDEN

VOLUME 6

I932-I933

Yale

UNIVERSITY PRESS

New Haven \& London 
First published in the

United States in 2016 by Yale University Press.

First published in

Great Britain in 2016 by Faber and Faber Limited.

All writings by T. S. Eliot, introductions, and editorial material () Set Copyrights Limited 2016.

All writings by Vivien Eliot () The Estate of Valerie Eliot 2016.

All rights reserved.

This book may not be reproduced,

in whole or in part, including illustrations, in any form

(beyond that copying permitted by Sections I07 and I08 of the U.S.

Copyright Law and except by reviewers for the public press), without written permission from the publishers.

Yale University Press books may be

purchased in quantity for educational, business, or

promotional use. For information, please e-mail sales.press@yale.edu

(U.S. office) or sales@yaleup.co.uk (U.K. office).

Typeset by Donald Sommerville.

Printed in the United States of America.

Library of Congress Control Number: 2016933960

ISBN 978-0-300-2I I 80-I (hardcover: alk. paper)

A catalogue record for this book is available from the British Library.

This paper meets the requirements of ANSI/NISO Z39.48-I992 (Permanence of Paper).

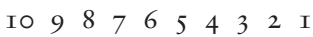

